British Journal of Economics, Management \& Trade
$12(4): 1-8,2016$, Article no.BJEMT.24507
ISSN: 2278-098X
SCIENCEDOMAIN international
www.sciencedomain.org

\title{
Effect of Trade Receivables and Inventory Management on SMEs Performance
}

\author{
Abdullahi Hassan Gorondutse ${ }^{1^{*}}$, Rahima Abass $\mathrm{Ali}^{2}$ and Abass $\mathrm{Ali}^{2}$ \\ ${ }^{1}$ School of Business Management, College of Business, Universiti Utara Malaysia, Malaysia and \\ Nigerian Police Academy Wudil, Kano State, Nigeria. \\ ${ }^{2}$ Sri Tiomon ii, Block 40 -01-04, Jalan Taman Melati 1/5, Setapak, 53100 Kuala Lumpur, Malaysia.
}

Authors' contributions

This work was carried out in collaboration between all authors. All authors read and approved the final manuscript.

Article Information

DOI: 10.9734/BJEMT/2016/24507

Editor(s):

(1) Chen Zhan-Ming, School of Economics, Renmin University of China, Beijing, China.

Reviewers:

(1) Marco Muscettola, Italy

(2) Sangeeta Sharma, D.A.V. Centanary College, Faridabad, India. (3) Fang Xiang, University of International and Business Economics, China. Complete Peer review History: http://sciencedomain.org/review-history/13632

Original Research Article

Received 23 $3^{\text {rd }}$ January 2016

Accepted 24 ${ }^{\text {th }}$ February 2016

Published 11 ${ }^{\text {th }}$ March 2016

\begin{abstract}
This paper investigates the effect of trade receivables and inventory management on SMEs profitability in Malaysia. 66 sample of SMEs Manufacturing covering from 2006-2012 was used for the analysis. Ordinary least square (OLS) regression is used to estimate the relationship between independent and dependent variable. The result indicated that days account receivable and inventory turnover in days are negatively related to SME profitability proxies i.e. return on assets $(\mathrm{ROA})$, return on equity (ROE) and net operating profit (NOP). The result implies that profitability of SME manufacturing depends upon effective of working capital components management. Therefore, the paper suggests that SME manufacturing can improve their Profitability upon managing working capital properly. Recommendations for future study were also discussed.
\end{abstract}

Keywords: Trade receivable; inventory management; SMEs performance.

\section{INTRODUCTION}

Working capital deals with the financial health of a company and it also plays important role in maximizing the shareholders wealth, hence, every company needs to sustain the balance between liquidity and profitability. Liquidity is a requirement to ensure that the firm is able to 
meet its short-term obligations Deloof [1], Padachi [2]. Working capital comprises the most liquid assets and it can be defined as the difference between current assets and current liabilities Paramasivan and Subramanian [3]. Thus, the relationship between current assets and current liabilities are the main theme of the theory of working capital management. Talat and Nazir [4], Smith [5] highlight that short-term assets and liabilities are important components of net working capital and therefore needs to be carefully analysed, since they play a key role for firm's profitability, risk, as well as its value. Indeed, companies might have an optimal level of working capital that counterbalances the costs and advantage of holding working capital and also maximizes their profitability or value Afza and Nazir [6], Afza and Nazir [7], Deloof [1] Gul et al. [8].

Further, small and medium enterprise (SMEs) are generally seen as small firms that are not efficiently managing their working capital (shortterm fund), but contribute to healthy and prosperous economy in every country and considered as a back bone of national economy Atrill [9], Amini [10], Radam, Abu and Abdullah [11]. Due to their limited access to the financial markets and over reliance on short-term funds, thus the efficient management of working capital is important for the existence, growth and profitability of SME companies Padachi [2], Pass and Pike [12].

Despite the difficulty in the external environment, Malaysian SMEs continue to expand at a faster pace than the overall economy, with real GDP growth of $6 \%$ in 2012. This tremendous achievement was due to strong domestic economic activity, the rise in income levels, favorable labour market conditions and continued access to financing. The projected growth of Malaysian SMEs will be around $5-6 \%$ for 2013 and 2014, while the overall GDP is projected against a backdrop of $4.5-5 \%$. Economic Transformation Program and the SME Master Plan initiatives together with domestic demand will be the pillars to reinforce and sustain the SME growth in the future SME annual report [13].

In line with the above, it is evident that there is a strong conviction of the need to intensify research on effective management of working capital and how it influences SMEs profitability especially in manufacturing companies of relatively developing economies like Malaysia where little has so far been done, and little been achieved. The study therefore seeks to address the theoretical and practical managerial problems and issues therein with a view to proffer solutions and recommendations based on the subsequent findings of the study.

\section{LITERATURE REVIEW}

\subsection{Working Capital Policies}

There are three main types of working capital policies which a firm may adopt such as Moderate policy, conservative policy, and aggressive policy. These policies describe the relationship between the sales level and the level of current assets.

\subsubsection{Moderate policy}

A moderate policy applies when the company fixed assets and part of its current assets are from long-term debt and equity. This policy focuses on matching risks to the returns expected. (In other word this approach results in a moderate amount of working capital and a moderate risk level). Under this policy Short term current assets are financed with short debts while non-current assets are financed with long term debts and equity. The disadvantage of this policy is it involved a lot of cost which will reduce the profitability of the firm Arnold [14].

\subsubsection{Conservative policy}

The company would try to adopt the conservative policy by taking a long term loan, because favor to use long term loan than short term debt. Under this policy Firm can reduce risks associated with short-term borrowing by using a larger proportion of long-term financing. Sathyamoorthi and Wally [15] Companies tend to adopt a conservative approach during the time of high business volatility. However, the disadvantage of this policy is that the company may experience a high cost for the long term loan resulted from the increase in the interest rate than the short term loan.

\subsubsection{Aggressive policy}

Aggressive working capital policy applies when the company's intention is to finance the permanent of the working capital through shortterm sources. This policy seeks to minimize the excess liquidity while meeting the short-term requirements. In this approach the firm may accept a great risk of insolvency in order to save the cost of long-term financing and also to earn greater return. According to Hussain, Farooz and Khan [16] aggressive policy relates with the 
firm's active control and management of current assets with the aim of minimizing them. Other things being equal, an aggressive policy leads in lower current assets, shorter cash conversion cycle, higher risk and higher returns to recompense the risk Pinches [17]. However, under this policy the company which has high risk strategy will get high return Hussain, Farooz and Khan [16] found when firm adopt an aggressive policy with low level of current assets it will result to increase their profitability.

\subsection{Working Capital Components}

\subsubsection{Trade receivables}

Receivables are often recorded in the company's balance sheet when sale of goods or services are on credit. Credit period is a period when a company's customer is given a specific period to settle the cash that he/she owes the company. Firms manage the receivables so that credit period is well known by the customer and when it's due Padachi [2]. The company accountant or credit collector usually carry out a credit analysis to gauge who are paying on time and who are not so as for the management to take any necessary action. When the company receives the cash early, it will improve the company's working capital and its efficiency. However, if a company stress too much on collecting cash too early from the customer might hamper the relationships between the parties and as such it will have negative impact on the business sales of the company in the long run as the customer might turn to the company's competitor.

Some companies uses factoring company by selling and handover their trade receivables so as to improve working capital and at same time get cash early Vural, Sokmen and Centenak [18]. And the factoring company will discount the trade receivables to make a profit and return rest of the money to the company. However, a company might have potential risk of using factoring facility, because the factoring company might treat the company's customer too harshly and having consequences on the company relationship with the customer Brealey, Myers and Allen [19].

\subsubsection{Inventory management}

Commonly, inventory is the second largest asset in a manufacturing firm. Mathuva [20] described inventory conversion cycle as the period taken to change inventory into sales. If inventory conversion period increases, cost of inventory will increase. Hence, the objective of inventory management is to lessen the cost of inventory without initiating distraction in the production Bhattacharya [21]. In every manufacturing company, inventory management is a vital makeup of current assets; inventories are often in the form of raw materials, works in progress or finished goods. To improve working capital and efficiency, management needs to balancing to keep inventory for sales and having less inventory as well. When there is less inventory when a customer demand has to be met immediately, the company will lose out on revenue if customer demand is not met Padachi [2].

However on the other side, company holding too much inventory will have an opportunity cost and may result to inventory obsolescence and additional cost like maintenance cost etc. moreover, previous research shows that the trend has been to lower inventory levels over the past decades. For example, 30 years ago U.S companies had approximately 12 percent of total assets tied up in inventory, whereas today the percentage is around 6 Vural, Sokmen and Centenak [18]. This is known as the Japanese concept of just-in-time, which is originated from Japan for managing their inventory level. The concept of just-in-time keeps suppliers ready to supply goods or stocks when the need arises for organization to satisfy customer demand. With this way, inventories are held at zero or in low levels Brealey, Myers and Allen [19].

\subsection{Review of Previous Empirical Studies}

The results of the previous studies that examine the relationship between working capital management and profitability both large and SME firms are mixed, but the majority of studies prove a negative relationship between working capital management and firm profitability. Jose, Lancaster and Stevens [22] study the relationship between aggressive working capital management (cash conversion cycle) and profitability of US firms. Their results conclude that there is a negative relationship between the cash conversion cycle and return on investment, a proxy for the firm's profitability. The result suggests that the more the aggressive working capital management is, the lower the profitability would be.

Shin and Soenen, [23] highlight the importance of efficient working capital management for 
corporate profitability in the U.S. Using a sample of 58985 listed American firms for the period of 1975-1994 they find a strong negative relationship between working capital management measured by net trade cycles (NTC) and corporate profitability. Their result suggests that managers can create value for their shareholders by reducing the NTC to a reasonable minimum level. examines whether working capital management has an effect on the profitability of Belgian firms. Utilizing a sample of 1,009 Belgian non- financial companies in the period of 1992-1996, the result demonstrates that there is a negative relationship between gross profit and receivables collection period, inventory period and payable period (proxies for working capital management). This implies that to increase the gross profit of the firm, managers should reduce the operating receivables collection period, inventory period and payable.

Shah and Sana [24] investigate the impact of working capital management on the profitability of oil and gas sector in Pakistan. They use receivable days, payable days, inventory days, current ratio, and quick ratio as working capital measures and gross operating income as profitability measure. Their result shows that there is a negative relationship between the gross operating income and working capital components, which implies that the increased in working capital leads to decreased in profitability of the firms.

Mohamad and Saad [25] conduct a study to measure the impact of working capital management and the performance of Malaysian listed companies for a sample of 172 companies between 2003 to 2007. They find that current assets to total asset ratio has a positive significant impact on the firm performance measured by (Tobin Q, ROA and ROI). While current asset to current liabilities ratio, Cash conversion cycle, and current liabilities to total assets ratio shows negative and significant relationship with Tobin Q, ROA and ROIC. Based on their results, they suggest that working capital components and performance in Malaysia disclose both negative and positive relationship.

Salawu and Alao [26] evaluate the effects of working capital management on the performance of Nigerian manufacturing firms for the periods $2000-2009$. The results of their study showed that there is a positive and significant relationship between average collection period and average payment period on profitability.
In the context of SMEs, García-Teruel and Martínez-Solano [27] examine the effects of working capital management in Spain. Utilizing a sample of 8,872 small to medium-sized enterprises (SMEs) for a period of 1996-2002, their result shows that there is a significant negative relation between SME profitability and the number of day's accounts receivable, days of inventory cash conversion cycle (proxies of working capital management). This shows that SMEs return on assets is reduced by lengthening the number of day's accounts receivable, number of days of inventory and cash conversion cycle. On the other hand, leverage/debt has negative effect with SME profitability while firm size and sales growth are positively related to SMEs profitability, so that large firm size and increase of company sales seems to favour the improvement of profitability. The finding of this study is similar to those found in previous studies that focused on large firms Jose, Lancaster and Stevens [22], SME annual report [13], Deloof [1]. Their study suggested that managers can create value by adopting the aggressive policy of working capital i.e. shortening their number of day's accounts receivable and inventories which will improve the firm's profitability.

Afeef [28] Study on the impact of working capital management on the profitability of SMEs in Pakistan for a period of 6 years from $2003-2008$. Their result showed a strong negative relationship of the inventory conversion period and receivable collection period with the operating profit to sales. This shows that an increase in inventory conversion period and receivable collection period will lead to decrease the operating profit to sales.

\subsection{Theoretical Framework}

Theoretical framework directs the research, determines what things that the study will measure, and what statistical relationships the study will look for. Previous researchers examine the effect of working capital management on profitability using large firms in Malaysia Mohamad and Saad [25]. However few researches that examine the effect of working capital management on SMEs profitability. Based on this, the framework of the study is constructed to ascertain the effect of working capital components such as days account receivable (DAR), inventory turnover in days (ITID), on SMEs profitability measured by return on assets $(\mathrm{ROA})$, net operating profit (NOP) and return on equity $(\mathrm{ROE})$. 
In line with the research framework discussed above the following hypotheses will developed in conjunction with research of the study.

\subsubsection{The Hypothesis 1}

$\mathrm{H} 0$ : There is a negative relationship between days account receivables and SMEs profitability.

Ha: There is a positive relationship between days accounts receivables and SMEs profitability.

\subsubsection{The Hypothesis 2}

$\mathrm{HO}$ : There is a negative relationship between inventory turnover in days and SMEs profitability.

$\mathrm{Ha}$ :There is a positive relationship between inventory turnover in days and SMEs profitability.

\section{METHODOLOGY}

This study used quantitative data Gorondutse and Hilman [29], the quantitative data used are from source of secondary data collected from annual financial reports of the SME companies. The data consists of account receivables, inventories, account payables, total debt, total equity, total current assets, total current liabilities, total assets, revenue or sales, profit after tax, and profit before tax. Companies Commission of Malaysia (CCM) is an autonomous body that functions as a center for corporate information, regulation and development of Malaysian companies. CCM database was used for collection of data. Thus, companies' financial figures were collected for the period of 20062012 which will use for the research purpose through individual company reports. The reason behind the selection particularly these years is the data between these periods is considered to be complete and accurate as they are not much missing data from the final data set.

The final sample of the study for the estimated model consists of 66 SMEs in the manufacturing sector. The purpose for selecting manufacturing firms is because manufacturing mostly deals with inventory at almost every stage of production (raw-materials until finished goods) compared to other sectors. Multiple regressions method are used to evaluate the relationship between working capital components and SMEs profitability measures by using the ordinary least squares (OLS) regression. The multiple regressions method was conducted by using EViews version 8. Correlation analysis and the descriptive statistics are analyzed using SPSS version 20. The models run are consistence with the models used in previous studies GarcíaTeruel and Martínez-Solano [27], Shah and Sana [24] and Zariyawati, Annuar, Taufiq and Rahim [30], Samiloglo and Demirguneş [31].

\section{RESULTS AND DISCUSSION}

The descriptive statistic show the average value of the return on asset (ROA), net operating profit (NOP) and return on equity (ROE) are $8.4 \%$, 86.6 and $6.7 \%$ respectively. This finding shows that SMEs in Malaysia are cost effective in generating more profit from their operations by utilizing their total assets. Furthermore the return to equity holders is considered to be is relatively to be moderate. The maximum value for ROA, NOP and ROE are $54.0 \%$ and $14.93 \%$ and $95.30 \%$ respectively. This indicates that SMEs in manufacturing sector shown a higher ROE with the maximum value of $95.30 \%$.

The SME firms receive payment from their customers at an average of days account receivables of 55.91 days. Moreover the SMEs in Malaysia tend to make earlier payment to their suppliers at an average of days account payables of 44.35 days before receiving money/payments from their customers. This maybe as a result of discount offered by the suppliers and also SMEs do not rely much on trade debt due to the ample initiatives and support from the government to finance their business operations see Table 1 for details.

The regression analyses are run to see if there is a presence of autocorrelation in the data, using Durbin Watson (DW) statistics. The scores of these statistical tests are accepted, implicating that there is no presence of autocorrelation in the data. The athour Makridakis and Wheelwright [32] consider D-W statistics values lie between 1.413 and 1.55, where a score of 2 indicate that there is no autocorrelation and 0 score indicating that there is autocorrelation. The authors Jose, Lancaster and Stevens [22] consider D-W value between 1.5 and 2.5 as acceptable level indicating no presence of autocorrelation. Some of these scores are somewhat lower than 1.5, but since the common rule indicate that score lower than 1.0 may cause alarm, these score are still accepted.

Pearson correlation test is conducted to examine the relationship between the dependent and independent variables. Table 2 demonstrates the correlation analysis all the variables used in the 
Table 1. Descriptive statistic

\begin{tabular}{llllll}
\hline Variables & $\mathbf{N}$ & Mean & Minimum & Maximum & Std deviation \\
\hline ROA & 526 & .0837 & .0002 & 5400 & .852 \\
NOP & 526 & .0865 & .0018 & 14.93 & 1.304 \\
ROE & 526 & .0674 & -4.313 & 95.30 & 37.87 \\
DAR & 526 & 55.91 & 7.400 & 70.67 & 39.70 \\
DAP & 526 & 44.35 & 3.431 & 75.61 & 69.30 \\
ITID & 526 & 68.55 & 60.27 & 136.7 & 79.28 \\
\hline
\end{tabular}

Table 2. Pearson correlation

\begin{tabular}{|c|c|c|c|c|c|c|}
\hline & ROA & NOP & ROE & DAR & DAP & ITID \\
\hline ROA & 1 & & & & & \\
\hline NOP & -.012 & 1 & & & & \\
\hline ROE & -.056 & $.093^{\star *}$ & 1 & & & \\
\hline DAR & $-.053^{*}$ & $-.176^{\star}$ & -.034 & 1 & & \\
\hline DAP & $.023^{* *}$ & $-.108^{*}$ & .034 & $.715^{*}$ & 1 & \\
\hline ITID & -.026 & $-.137^{*}$ & -.045 & $.195^{*}$ & $.073^{\star \star}$ & 1 \\
\hline
\end{tabular}

study. It shows that SMEs days account receivable is having negative correlation with the three dependent variables i.e., ROA, NOP and ROE while days account payable positive correlation with ROA and ROE but negative correlation with NOP. Furthermore inventory turnover in days are having negative correlation with three dependent variables. Moreover DAR and DAP are having high correlation of 0.715 .

In addition, ITID is also having a correlation of 0.731 . And these correlations are statistically significant at the $1 \%$ level and $5 \%$ confidence level. But all other independent variables in the in the model are considered to have low correlations. And these correlations are statistically significant at the $1 \%$ and $5 \%$ confidence level.

Multicollinearity is not a problem to this study as indicated by the low pair-wise correlation among the variables. To confirm that multicollinearity is not a problem to this study, a variance inflating factor (VIF) is reported in Table 3. The R-square are relatively low for all the variables which give a lower VIF at the range of 1.337 to 2.153 indicating there is no problem of multicollinearity in this study see Table 3.

Table 3. Multicollinearity

\begin{tabular}{lll}
\hline Variables & R2 & VIF \\
\hline DAP & 0.535 & 2.149 \\
DAR & 0.252 & 1.337 \\
ITID & 0.536 & 2.153 \\
\hline
\end{tabular}

Moreover the result also shows that days account payable (DAP) has a positive and significant effect on SMEs profitability, this indicate that the later the Malaysian SMEs pay their bills to their suppliers will tend to increase their profit. The finding is in line with that of Dinku [33] who examine the Ethiopian SMEs and finds that day in account payable is positively related to the profitability of the SMEs, this relationship has accepted the null Hypothesis $1: \mathrm{Ha}$, Hypothesis 2: Ha.

Overall, these findings suggests that SMEs in Malaysia are relying much on short-term trade financing to finance their operations as DAP positively related to profitability of SMEs. Management of SMEs can also shorten DAR to increase the profitability of the firm. Moreover, we can also say that by sustaining a minimum DAR companies will be able to better maximize their sales which will improve the profitability.

The result from the regression shows that using NOP as the dependent variable, DAR, DAP and ITID are all negatively related to profitability of SMEs. DAR is significant at $1 \%$ confidence level, ITID is significant at $5 \%$ level, but DAP is found not to be significant. To increase the net operating profit, the SMEs need to reduce the level of their account receivables, inventory and account payables. Overall, the results are consistence with the findings of Shah and Sana [24]; Jose, Lancaster and Stevens [22]. Moreover, under this relationship has accepted the null Hypothesis 1: $\mathrm{HO}$, Hypothesis 2: $\mathrm{HO}$.

However the three variables are not statistically significant in measuring their effects on SMEs profitability using ROE as proxy. DAP has a 
positive relations with $\mathrm{ROE}$ and statistically significant at $5 \%$ confidence level. This implies that, an increase in the level of SMEs account payables will result with an increase in the company's profitability. Similar to previous findings, all control variables are insignificant under ROE also. Therefore this relationship accepted the null Hypothesis 1:H0, Hypothesis 2: $\mathrm{HO}$. It is interesting to note that, the findings of this study in the aspect of ROE supports Mohamad and Saad [25], Deloof [1] in this respect, Hong, Ayrton and Fábio [34] investigate the relationship between working capital and profitability in Brazil. Their study finds that day's inventory does not have any statistical evidence when measured with ROE as measure of profitability. We can further argue that ROE is not a good proxy for SMEs profitability as compared to ROA and NOP.

\section{CONCLUSION}

The results show that, there is some negative relationship between working capital management measures i.e. days account receivables (DAR), inventory turnover in days (ITID), and SMEs profitability proxies i.e. return on assets (ROA), return on equity (ROE) and net operating profit (NOP). The results imply that Profitability of SME manufacturing firms depends upon effective working capital management. Therefore, this study suggests that SMEs managers can improve the profitability of their firms by reducing their cash conversion cycle which is the components of days account receivable (DAR), inventory turnover in days (ITID). Despite the limitation of the study this study focused mainly on Malaysian SMEs in manufacturing sector, this implies that these results cannot generalize to include SMEs in other sectors. Future research can conduct a comparative analysis can also be done between Malaysia and other countries in order to identify country specific factors on the effect of working capital on profitability of SMEs.

\section{COMPETING INTERESTS}

Authors have declared that no competing interests exist.

\section{REFERENCES}

1. Deloof D. Does working capital management affect profitability of Belgian firms? Journal of Business Finance and Accounting. 2003;30(3 \& 4):573-587.
2. Padachi Kesseven. Trends in working capital management and its impact on firms' performance: An analysis of mauritian small manufacturing firms. International Review of Business Research. 2006;2(2):45-58.

3. Paramasivan C, Subramanian T. Financial management. New Delhi: New Age International Pvt Ltd Publishers. Electronic text Book; 2008/2009.

4. Talat A, Nazir M. Working management efficiency, of cement sector of Pakistan. Journal of Economics and Behavioral Studies. 2011;2:223-235.

5. Smith KV. State of the art of working capital management. Financial Management, Autumn. 1980;50-55

6. Afza T, Nazir MS. Working capital management policies of firms: Empirical evidence from Pakistan. Conference Proceedings of 9th South Asian Management Forum (SAMF) on February 24-25, North South University, Dhaka, Bangladesh; 2007.

7. Afza T, Nazir MS. Impact of aggressive working capital management policy on firms 'profitability. The IUP Journal of Applied Finance. 2009;15(8):20-30.

8. Gul S, Khan MB, Raheman SU, Khan MT, Khan M, Khan W. Working capital management and performance of SME sector. European Journal of Business and Management. 2013;5(1):60-68.

9. Atrill P. Financial management for decision maker, (4 ${ }^{\text {th }}$ edition) practice hall; 2006.

10. Amini Amin. The distribution a I role of small business in development. International Journal of Social Economics. 2004;31(4).

11. Radam Aalias, Abu, Bmimi Liana, Abdullah, Camin Mahir. Technical efficiency of small and medium enterprise in Malaysia: A stochastic frontier production model. International Journal of Economics and Management. 2008;2(2).

12. Pass $\mathrm{C}$, Pike RH. Management of working capital: A neglected subject. Management Decision. 1987;25(1):18-24.

13. SME annual report, (2012/2013). National SME Development Council.

Available:http://www.smecorp.gov.my/vn2/ node/717

14. Arnold G. Corporate financial management. 4th Ed. England. Pearson Education Limited; 2008.

15. Sathyamoorthi CR, Wally - Dima LB. Working capital management: The case of 
listed rental domestic companies in Botswana. The ICFAIAN Journal of Management Research. 2008;7(5):7-24.

16. Hussain A, Farooz SU, Khan KU. Aggressiveness and conservativeness of working capital: A case of Pakistan Manufacturing Sector, European Journal of Scientific Research. 2012;73(2):171-182.

17. Pinches G. Essentials of financial management. New York: Harper Collis Publishing; 1997.

18. Vural G, Sokmen A, Centenak E. Effects of working capital management on firm's performance: Evidence from Turkey. International Journal of Economics and Financial Issues. 2012;2(4):488-495.

19. Brealey R, Myers S, Allen. Working capital management, corporate finance, New York: Mcgraw Hill; 2006.

20. Mathuva M. David. The influence of working capital management components on corporate profitability: A survey on Kenyan listed firm. Research Journal of Business Management. 2011;4(1).

ISSN 1819-1932.

21. Bhattacharya H. Working capital management, strategies and techniques. New Delhi: Prentice hall; 2003.

22. Jose ML, Lancaster C, Stevens JL. Corporate returns and cash conversion cycles. Journal of Economics and Finance. 1996;20(1):33-46.

23. Shin $\mathrm{HH}$, Soenen L. Efficiency of working capital and corporate profitability. Financial Practice and Education. 1998;8:37-45.

24. Shah SMA, Sana A. Impact of working capital management on the profitability of oil and gas sector of Pakistan. European Journal of Scientific Research. 2006; 15(3).

25. Mohamad NEAB, Saad NBM. Working capital management: The effect of market valuation and profitability in Malaysia. International Journal of Business and Management. 2010;5(11).
26. Salawu RO, Alao JA. Working capital management and the performance of selected quoted manufacturing companies in Nigeria. Research Journal of Finance and Accounting. 2014;5(14).

27. García-Teruel PJ, Martínez-Solano P. Effects of working capital management on SME profitability. International Journal of Managerial Finance. 2007;3(2):164 - 177.

28. Afeef Mustafa. The impact of working capital management on the profitability of SME's in Pakistan. International Journal of Business and Social Science. $2011 ; 2(22) \mathrm{D}$.

29. Gorondutse $\mathrm{AH}$, Hilman $\mathrm{H}$. Examining corporate reputation and commitment to business social responsibility (BSR) on Organizational Performance Relations: Evidence from Manufacturing Sector in Nigeria. European Journal of Business and Management. 2013;5(10):71-89.

30. Zariyawati M, Annuar M, Taufiq H, Rahim A. Working capital management and orate performance: Case of Malaysia. Journal of Modern Accounting and Auditing. 2009; 5(11):47-54

31. Samiloglo F, Demirguneş K. The effect of working capital management on firm profitability: Evidence from Turkey. The International Journal of Applied Economics and Finance. 2008;2(1):44-50.

32. Makridakis S, Wheelwright SC. Interactive forecasting univariate and multivariate methods. California: Holden-Day Inc; 1978.

33. Dinku Tirngo. Impact of working capital management on profitability of micro and small enterprises in Ethiopia: The case of Bahir Dar City administration. International Journal of Accounting and Taxation. 2013;1(1).

34. Hong Yuh Ching, Ayrton Novazzi, Fábio Gerab. Relationship between working capital management and profitability in Brazilian listed companies. Journal of Global Business and Economics. 2011;3.

(c) 2016 Gorondutse et al.; This is an Open Access article distributed under the terms of the Creative Commons Attribution License (http://creativecommons.org/licenses/by/4.0), which permits unrestricted use, distribution, and reproduction in any medium, provided the original work is properly cited.

Peer-review history:

The peer review history for this paper can be accessed here: http://sciencedomain.org/review-history/13632 